\title{
Astronomical climate control on paleosol stacking patterns in the upper Paleocene-lower Eocene Willwood Formation, Bighorn Basin, Wyoming
}

\author{
Hayfaa Abdul Aziz* \\ Frits J. Hilgen \\ Gerson M. van Luijk $\rfloor$ Netherlands \\ Appy Sluijs Palaeoecology, Institute of Environmental Biology, Faculty of Science, Utrecht University, \\ Laboratory of Palaeobotany and Palynology, Budapestlaan 4, 3584 CD Utrecht, Netherlands \\ Mary J. Kraus Department of Geological Sciences, University of Colorado, Boulder, Colorado 80309, USA \\ Josep M. Pares
Philip D. Gingerich - Department of Geological Sciences, University of Michigan, Ann Arbor, Michigan 48109, USA
}

\begin{abstract}
The Willwood Formation of the Bighorn Basin (Wyoming, USA) is a thick succession of upper Paleocene and lower Eocene fluvial-floodplain sandstones and mudstones. Reddish paleosols, formed on the floodplain mudstones, alternate rhythmically on various scales with heterolithic intervals of small-channel sandstones and mudstones showing weak pedogenesis. Spectral analysis of redness in the Willwood successions at Polecat Bench and Red Butte reveals significant spectral peaks corresponding to cycle thicknesses of $\sim 8$ and $\sim 3 \mathrm{~m}$. The $\sim 8 \mathrm{~m}$ cycle reflects distinct clusters of 3-5 paleosols. Age constraints show that the period of this cycle closely matches the $\sim 21$ k.y. climatic precession cycle. The $\sim 3 \mathrm{~m}$ cycle corresponds to individual paleosols, with a period of 7-8 k.y. This period is similar to millennial-scale sub-Milankovitch cycles found in marine and lacustrine successions of Pliocene-Pleistocene age. Precession and millennial-scale climate variations probably affected paleosol development through cyclic changes from predominantly overbank to predominantly channel-avulsion deposition, with the latter periodically halting soil formation because of high sediment accumulation. A new age model was developed for the Paleocene-Eocene carbon isotope excursion (CIE) at Polecat Bench, based on the precessional origin of paleosol clusters. The main body of the CIE spans $\sim 5.5$ precession cycles, or $\sim 115 \mathrm{k} . \mathrm{y}$., and the recovery tail of the CIE spans 2 precession cycles, or $\sim 42$ k.y. This outcome is consistent with, and independently confirms, recent estimates of CIE duration based on deep-sea cores.
\end{abstract}

Keywords: paleosols, Milankovitch theory, spectral analysis, Bighorn Basin, avulsion.

\section{INTRODUCTION}

The upper Paleocene-lower Eocene Willwood Formation of the Bighorn Basin, Wyoming, is a spectacularly color-banded succession of fluvial deposits rich in mammalian fossils (Van Houten, 1944; Gingerich and Clyde, 2001). The bright color bands are dominantly red paleosols, while other colors range from orange to purple (Bown and Kraus, 1981; Kraus, 1997).

A striking aspect of the Willwood paleosols is their rhythmic stacking pattern, which has been attributed to autocyclic floodplain development (Kraus and Gwinn, 1997; Clyde and Christensen, 2003), tectonics (Bown and Kraus, 1993), or climate. The last hypothesis includes the possibility of orbitally induced climate changes (previously suggested by Kraus and Aslan, 1993), but the mechanism requires further elaboration.

The impact of orbitally induced climate oscillations on terrestrial sedimentary cycles remains largely unstudied. During the past decade, accurate time control has provided evidence that different scales of hierarchically arranged sedimentary cycles are climatically linked and orbitally forced in continental successions of the Triassic Newark Basin,

*Current address: Deltares/TNO, Geological Survey of the Netherlands, Princetonlaan 6, 3508 AL Utrecht, Netherlands; e-mail: haziz@geo.uu.nl.
Eocene Green River Formation, and Mediterranean Neogene (Olsen et al., 1996; Abdul Aziz et al., 2003; Machlus et al., 2008). These are all lacustrine environments, which are considered more sensitive to record astronomically forced climate change than fluvial settings due to the reduced influence of autogenic processes. Orbital climate forcing is the only working hypothesis of paleosol cyclicity that has well-defined expectations in terms of cycle thickness and cycle durations. We test orbital climate forcing using time series analysis of high-resolution color records in paleosolrich sections of the Willwood Formation in the Bighorn Basin.

\section{SECTIONS AND METHODS}

Two sections of the Willwood Formation have been studied in detail (Fig. 1). The Polecat Bench (PCB) section in the northern Bighorn Basin spans the Paleocene-Eocene thermal maximum at the Paleocene-Eocene boundary (ca. 55.5 Ma) (e.g., Bowen et al., 2001). The Red Butte (RB) section in the central Bighorn Basin includes part of chron C24n and was deposited $~ 53$ m.y. ago (Clyde et al., 2007). Both sections are a composite of several subsections (GSA Data Repository Figs. DR1 and DR2 $2^{1}$ ) and comprise a continuous record of paleosols without incised channel sandstones (Fig. 2).

In the field, paleosols occur in repetitive clusters of 3-5 individual paleosols, with a cluster thickness of 7-9 m (Figs. 2A and 2B). To quantify the clustering, color measurements were taken at an average sampling distance of 14.5 and $21 \mathrm{~cm}$ in the PCB and RB paleosol sections, respectively, using a portable photospectrometer (Minolta CM508i). Spectral analysis of the redness ( $\mathrm{a}^{*}$ value) color records was used to evaluate paleosol cyclicity (color data in Tables DR1 and DR2). Blackman-Tukey and CLEAN analysis methods were applied using AnalySeries (Paillard et al., 1996) and MC-CLEAN (Heslop and Dekkers, 2002), respectively.

\section{SPECTRAL ANALYSIS RESULTS}

Spectral analysis of the $\mathrm{a}^{*}$ color records reveals distinct peaks at 7.7/7.4 and $3.3 \mathrm{~m}$ in the PCB section, and at 8.7 and $2.6 \mathrm{~m}$ in the RB section (Figs. 3C and 3D). These peaks occur in both the Blackman-Tukey and MC-CLEAN power spectra, and are at or above the $93 \%$ significance level in the latter spectrum (Figs. 3C and 3D). A Gaussian bandpass filter was used to extract the spectral components. Filtered records of the 7.7 and $8.7 \mathrm{~m}$ components indicate that they correspond to paleosol clusters observed in the field (Figs. 3A and 3B). The 3.3 and 2.6 m filtered components follow individual paleosols within a cluster. In the MC-CLEAN power spectrum of PCB, two other peaks occur at 14 and $59 \mathrm{~m}$. These components, however, are weakly resolved in the reconstructed MC-CLEAN signal, due to the dominance of the $3.3 \mathrm{~m}$ and $7.7 \mathrm{~m}$ spectral components (red line, Figs. 3A and 3B).

${ }^{1}$ GSA Data Repository item 2008131, Figures DR1 and DR2 (detailed maps of Polecat Bench and Red Butte sections), Tables DR1 and DR2 (color data sets for Polecat Bench and Red Butte), and Supplemental Text DR1, is available online at www.geosociety.org/pubs/ft2008.htm, or on request from editing@geosociety. org or Documents Secretary, GSA, P.O. Box 9140, Boulder, CO 80301, USA. 


\section{TIME CONTROL AND INTERPRETATION}

The meter level of the top of $\mathrm{C} 24 \mathrm{r}$ in the PCB section is estimated by slight extrapolation, comparing meter levels of the base of $\mathrm{C} 24 \mathrm{r}$, the Paleocene-Eocene boundary, and first appearance datum of Bunophorus in the PCB section to coincident levels in nearby Foster Gulch and McCullough Peaks sections (see Supplemental Text DR1 in the Data Repository). Chron C24r is 1219 m thick in PCB and the sedimentation rate, based on the astronomical duration of $3118 \mathrm{k}$.y. for C24r (Westerhold et al., 2007), implies that the two orbital precession components of 19 and $23 \mathrm{k} . \mathrm{y}$. correspond to cycle thicknesses of 7.4 and $9 \mathrm{~m}$, respectively. Hence, the 7.7/7.4 m cycle in the PCB power spectrum (Fig. 3C) corresponds to the Milankovitch precession frequency. Age constraints further imply that the $3.3 \mathrm{~m}$ cycle has a period of $\sim 8 \mathrm{k} . \mathrm{y}$.

Paleomagnetic and radiometric constraints for the RB area are less certain (Clyde et al., 2007) and are not considered very precise for estimating sediment accumulation rates (see Supplemental Text DR1). We developed an independent comparison for sediment accumulation in the two areas, using regression analysis of evolutionary trends in changing tooth size for the fossil mammals Haplomylus and Cantius (Supplemental Text DR1). Matching trends indicates slightly higher sediment accumulation in the PCB section for one taxon and in the RB section for the other. Both together indicate that lower Eocene sediment accumulated at approximately the same rate in both parts of the Bighorn Basin. Our approach yields expected durations of $22.3 \mathrm{k} . \mathrm{y}$. for the $8.7 \mathrm{~m}$ cycle and $6.7 \mathrm{k} . \mathrm{y}$. for the $2.6 \mathrm{~m}$ cycle. The former is again consistent with precession.

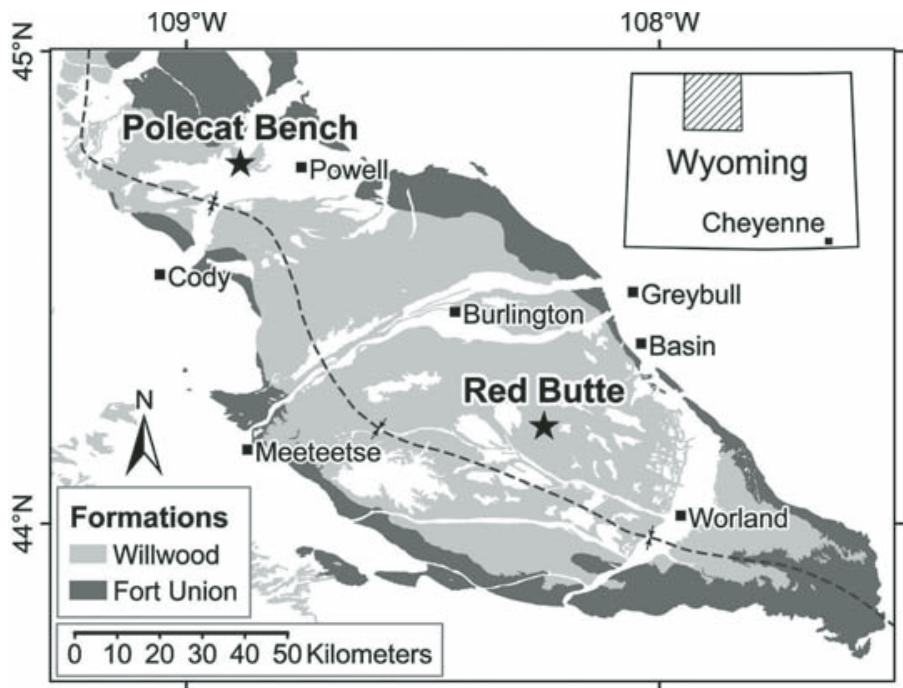

Figure 1. Geological map of Bighorn Basin, Wyoming, showing locations of Polecat Bench and Red Butte sections (detailed maps in Figs. DR1 and DR2; see footnote 1). Geology from Love and Christiansen (1985).

\section{DISCUSSION AND CONCLUSIONS}

Robustness of our spectral analyses and available time control indicate that each cluster of 3-5 paleosols at PCB and RB corresponds to the 21 k.y. climatic precession cycle. To test this outcome we compared a new estimate for duration of the CIE based on counts of precession cycles at Polecat Bench with CIE durations estimated in other settings.

The CIE in the PCB section is identified in the $\delta^{13} \mathrm{C}$ record of soil nodule carbonate and dispersed organic carbon (Bowen et al., 2001; Magioncalda et al., 2004). The main body of the CIE is between $22 \mathrm{~m}$ and $62.5 \mathrm{~m}$ in the stratigraphic section of Figure $3 \mathrm{~A}$, and it contains $\sim 5.5$ paleosol clusters. The CIE recovery interval ends at $\sim 77 \mathrm{~m}$, including two additional paleosol clusters (Fig. 3A). Multiplying the number of clusters by 21 k.y., the duration of the main body of the CIE in PCB is 115 k.y., and that of the recovery interval is $\sim 42 \mathrm{k} . \mathrm{y}$. The total CIE duration is $\sim 157$ k.y., which compares well with a recent estimate of $\sim 170$ k.y., based on cycle counts in a deep-marine section (Röhl et al., 2007). It also agrees with independent estimates ranging from 120 to $170 \mathrm{k} . \mathrm{y}$., based on extraterrestrial ${ }^{3} \mathrm{He}$ (Farley and Eltgroth, 2003) and average sedimentation rates derived from the astronomical duration of C24r (Sluijs et al., 2007).

Our results demonstrate that clusters of 3-5 paleosols accumulated on an orbital-precession time scale in both the PCB and RB sections, sug-
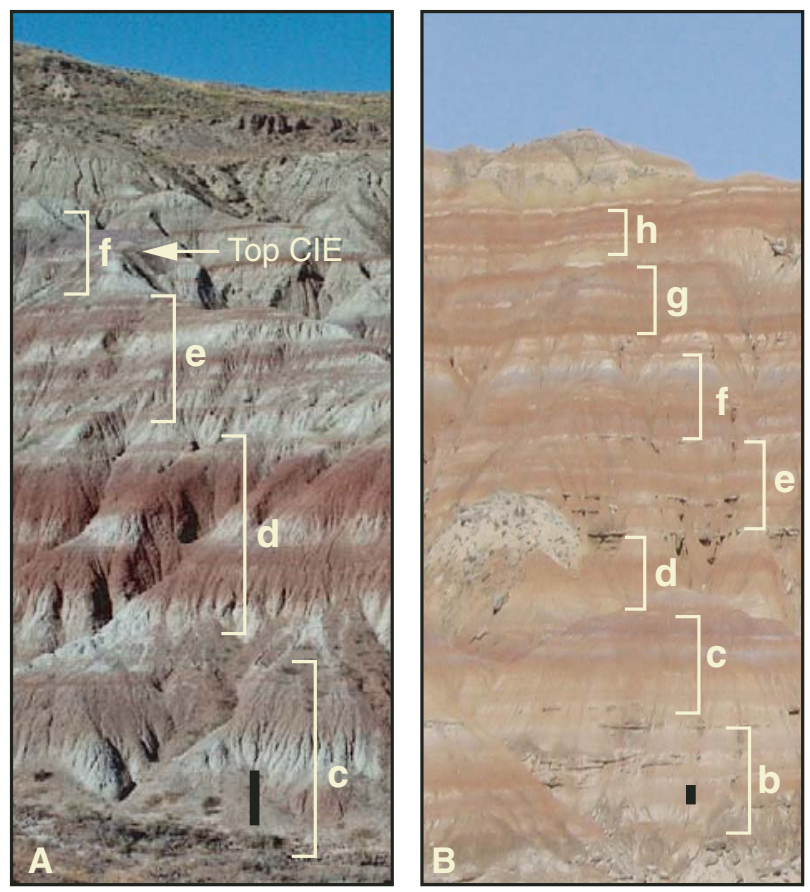

Figure 2. Photographs showing paleosol clusters. A: Polecat Bench section. B: Red Butte section. Black bar for scale is $2 \mathrm{~m}$ long. Labels correspond to clusters recognized in the field (see Fig. 3).

Figure 3. Lithology and color record for Polecat Bench and Red Butte stratigraphic sections (data sets in Tables DR1 and DR2; see footnote 1). A: Polecat Bench section showing lithological log, redness record (a* of Commission Internationale de l'Eclairage), and Gaussian filtered components of a*. Lithological log shows sandstones and mudstones, with sandstones projecting. Drab mudstones and sandstones are shown in gray. Paleosols are in purple and red hues; dark hues correspond to well-developed paleosols, light hues correspond to weakly developed paleosols. Carbon isotope excursion (CIE) soil nodule record (3 point moving average) is from Bowen et al. (2001) and dispersed organic carbon (DOC) record is from Magioncalda et al. (2004). Square brackets show precession-scale paleosol clusters recognized in the field (labels match Fig. 2). The $a^{*}$ record is from color measurements on in situ sediment surfaces in the field. Red line is reconstructed MC-CLEAN signal for frequencies above $93 \%$ significance level. Gaussian filtered components are centered at frequencies $0.3053 \pm 0.0670(3.3 \mathrm{~m})$ and $0.1300 \pm 0.0345(7.7 \mathrm{~m})$. Temporal calibration of $7.7 \mathrm{~m}$ filter of $\mathrm{a}^{\star}$ assumes precession cycle duration of $21 \mathrm{k} . \mathrm{y}$. B: Red Butte section showing lithology, $a^{*}$, and filtered components, as in A. The $a^{*}$ record is from measurements on discrete samples collected from the field. Gaussian filters are centered at frequencies $0.3844 \pm 0.055(2.6 \mathrm{~m})$ and $0.1156 \pm 0.047(8.7 \mathrm{~m})$. C, D: Blackman-Tukey (BT; above) and MC-CLEAN (below) power spectra for $a^{*}$ records of Polecat Bench and Red Butte. BT spectrum (and Gaussian filters) obtained using AnalySeries of Paillard et al. (1996). Gray shading is $90 \%$ confidence band. MC-CLEAN spectrum was obtained using MC-CLEAN of Heslop and Dekkers (2002). The $a^{*}$ time series was bootstrapped to $50 \%$ of its original length (1000 iterations; input parameters as recommended by Heslop and Dekkers, 2002). Horizontal red lines show $93 \%$ significance across all frequencies. Numbers in spectra correspond to cycle thicknesses in meters. 
gesting that paleosol stacking patterns in the Willwood Formation of the Bighorn Basin were controlled by precession forced climate change. In the PCB and RB sections, moderately to strongly developed red to purple(-red) paleosols formed on mudstones. Mudstones are interpreted as overbank deposits that accumulated slowly enough to form relatively mature paleosols. These alternate regularly with drab colored heterolithic intervals of sandstones and gray mudstones, interpreted as rapidly emplaced channel avulsion deposits (Kraus and Aslan, 1993; Kraus and Gwinn, 1997). Climate most likely affected soil development through its impact on channel avulsion. Precession-controlled clusters of paleosols formed through periodic changes from slow overbank-dominated to more rapid avulsiondominated accumulation. Slow overbank deposition permitted paleosol development and maturation, while rapid channel avulsions deposited sufficient sediment to bury a paleosol and halt its further development.
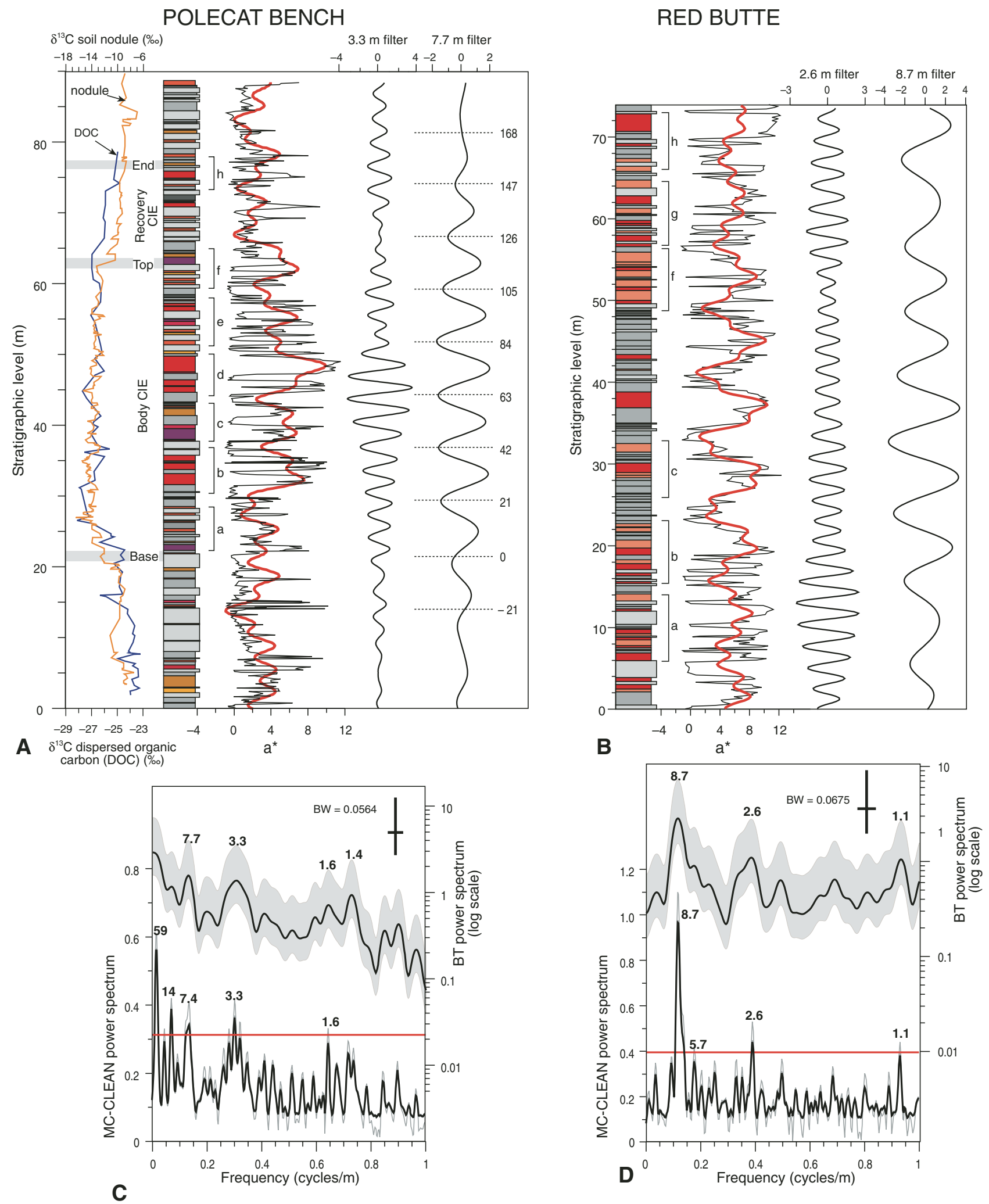
Precession-controlled climate most likely involves changes in precipitation and/or net evaporation. Lawrence et al. (2003) used a general circulation model to study Eocene terrestrial climate response to precession. They found $<10 \%$ precipitation change between minimum and maximum precession, and suggested that sedimentary cycles only develop in environments highly sensitive to changes in precipitation and/or evaporation, such as the lacustrine Wilkins Peak member of the Eocene Green River Formation (cf. Machlus et al., 2008). Our study demonstrates that precession-controlled cyclicity is also recorded in the less sensitive fluvial environment of the Willwood Formation.

Regular meter-scale cycles of individual paleosols occur on a subMilankovitch or millennial time scale that may also reflect climate change. Their duration of 7-8 k.y. is comparable to that found in Pliocene and Pleistocene marine and continental successions (e.g., Bond et al., 1993; Steenbrink et al., 2003; Becker et al., 2005). However, the exact origin of sub-Milankovitch cycles remains enigmatic. They have been attributed to ice-sheet dynamics (Bond et al., 1993), harmonics of the Milankovitch cycles (McIntyre and Molfino, 1996), or periodic motions of the Earth and moon (Keeling and Whorf, 2000).

Larger scale bundles of paleosol clusters on the short (100 k.y.) eccentricity time scale have been recognized in the field; however, longer cycles have not been documented in the color records because of the limited length of the sections studied. Analysis of longer records is necessary to demonstrate the expected 1:5 thickness ratio of $100 \mathrm{k} . \mathrm{y}$. eccentricity with precession.

\section{ACKNOWLEDGMENTS}

This research was supported by the U.S. National Science Foundation (grant EAR-0125502 to Gingerich, and EAR-0228858 to Kraus) and the Utrecht Biogeology Centre (to Sluijs). We thank Hemmo Abels for fruitful discussions, and Gabriel Bowen, Paul Koch, and Stuart Robinson for reviewing the manuscript.

\section{REFERENCES CITED}

Abdul Aziz, H., Hilgen, F.J., Krijgsman, W., and Calvo, J.P., 2003, An astronomical polarity time scale for the late middle Miocene based on cyclic continental sequences: Journal of Geophysical Research, v. 108, no. B3, 2159, doi: 10.1029/2002JB001818.

Becker, J., Hilgen, F.J., Lourens, L.J., Kouwenhoven, T., and Van der Laan, E., 2005, Late Pliocene climate variability on Milankovitch to millennial time scales: High-resolution study of MIS100 from the Mediterranean: Palaeogeography, Palaeoclimatology, Palaeoecology, v. 228, p. 338-360, doi: 10.1016/j.palaeo.2005.06.020.

Bond, G., Broecker, W., Johnson, S., McManus, J., Labeyrie, L., Jouzel, J., and Bonani, G., 1993, Correlations between climate records from North Atlantic sediments and Greenland Ice: Nature, v. 365, p. 143-147, doi: $10.1038 / 365143 \mathrm{a} 0$

Bown, T.M., and Kraus, M.J., 1981, Lower Eocene alluvial paleosols (Willwood Formation, northwest Wyoming, USA) and their significance for paleoecology, paleoclimatology, and basin analysis: Palaeogeography, Palaeoclimatology, Palaeoecology, v. 34, p. 1-30, doi: 10.1016/0031-0182(81)90056-0.

Bown, T.M., and Kraus, M.J., 1993, Time-stratigraphic reconstruction and integration of paleopedologic, sedimentologic, and biotic events (Willwood Formation, Lower Eocene, northwest Wyoming, USA): Palaios, v. 8, p. 68-80, doi: 10.2307/3515222.

Bowen, G.J., Koch, P.L., Gingerich, P.D., Norris, R.D., Bains, S., and Corfield, R.M., 2001, Refined isotope stratigraphy across the continental PaleoceneEocene boundary on Polecat Bench in the Northern Bighorn Basin, in Gingerich, P.D., ed., Paleocene-Eocene stratigraphy and biotic change in the Bighorn and Clarks Fork Basins, Wyoming: University of Michigan Papers on Paleontology, v. 33, p. 73-88.

Clyde, W.C., and Christensen, K.E., 2003, Testing the relationship between pedofacies and avulsion using Markov analysis: American Journal of Science, v. 303, p. 60-71, doi: 10.2475/ajs.303.1.60.

Clyde, W.C., Hamzi, W., Finarelli, J.A., Wing, S.L., Schankler, D., and Chew, A., 2007, Basin-wide magnetostratigraphic framework for the Bighorn Basin, Wyoming: Geological Society of America Bulletin, v. 119, p. 848-859, doi: 10.1130/B26104.1.

Farley, K.A., and Eltgroth, S.F., 2003, An alternative age model for the PaleoceneEocene thermal maximum using extraterrestrial 3He: Earth and Planetary Science Letters, v. 208, p. 135-148, doi: 10.1016/S0012-821X(03)00017-7.
Gingerich, P.D., and Clyde, W.C., 2001, Overview of mammalian biostratigraphy in the Paleocene-Eocene Fort Union and Willwood formations of the Bighorn and Clarks Fork basins, in Gingerich, P.D., ed., PaleoceneEocene stratigraphy and biotic change in the Bighorn and Clarks Fork basins, Wyoming: University of Michigan Papers on Paleontology, v. 33, p. $1-14$.

Heslop, D., and Dekkers, M.J., 2002, Spectral analysis of unevenly spaced climatic time series using CLEAN: Signal recovery and derivation of significance levels using a Monte Carlo simulation: Physics of the Earth and Planetary Interiors, v. 130, p. 103-116, doi: 10.1016/S0031-9201(01)00310-7.

Keeling, C.D., and Whorf, T.P., 2000, The 1800-year oceanic tidal cycle: A possible cause of rapid climate change: National Academy of Sciences Proceedings, v. 97, p. 3814-3819, doi: 10.1073/pnas.070047197.

Kraus, M.J., 1997, Early Eocene alluvial paleosols: Pedogenic development, stratigraphic relationships, and paleosol/landscape associations: Palaeogeography, Palaeoclimatology, Palaeoecology, v. 129, p. 387-406, doi: 10.1016/S0031-0182(96)00056-9.

Kraus, M.J., and Aslan, A., 1993, Eocene hydromorphic paleosols: Significance for interpreting ancient floodplain processes: Journal of Sedimentary Petrology, v. 63, p. 453-463.

Kraus, M.J., and Gwinn, B.M., 1997, Controls on the development of early Eocene avulsion deposits and floodplain paleosols, Willwood Formation, Bighorn Basin: Sedimentary Geology, v. 114, p. 33-54, doi: 10.1016/ S0037-0738(97)00083-3.

Lawrence, K.T., Sloan, L.C., and Sewall, J.O., 2003, Terrestrial climate response to precessional orbital forcing in the Eocene, in Wing, S.L., et al., eds. Causes and consequences of globally warm climates in the early Paleogene: Geological Society of America Special Paper 369, p. 463-478.

Love, J.D., and Christiansen, A.C., 1985, Geologic map of Wyoming: U.S. Geological Survey, 1 sheet, scale 1:500,000.

Machlus, M.L., Olsen, P.E., Christie-Blick, N.N., and Hemming, S.R., 2008, Spectral analysis of the lower Eocene Wilkins Peak Member, Green River Formation, Wyoming: Support for Milankovitch cyclicity: Earth and Planetary Science Letters, doi: 10.1016/j.eps1.2007.12.024.

Magioncalda, R., Dupuis, C., Smith, T., Steurbaut, E., and Gingerich, P.D., 2004, Paleocene-Eocene carbon isotope excursion in organic carbon and pedogenic carbonate: Direct comparison in a continental stratigraphic section: Geology, v. 32, p. 553-556, doi: 10.1130/G20476.1.

McIntyre, A., and Molfino, B., 1996, Forcing of Atlantic equatorial and subpolar millennial cycles by precession: Science, v. 274, p. 1867-1870, doi: 10.1126/science.274.5294.1867.

Olsen, P.E., Kent, D.V., Cornet, B., White, W.K., and Schlische, R.W., 1996, High-resolution stratigraphy of the Newark rift basin (early Mesozoic, eastern North America): Geological Society of America Bulletin, v. 108, p. 40-77, doi: 10.1130/0016-7606(1996)108<0040:HRSOTN>2.3.CO;2.

Paillard, D.L., Labeyrie, L., and Yiou, P., 1996, Macintosh program performs time-series analysis: Eos (Transactions, American Geophysical Union), v. 77 , p. 379, doi: 10.1029/96EO00259.

Röhl, U., Westerhold, T., Bralower, T.J., and Zachos, J.C., 2007, On the duration of the Paleocene-Eocene Thermal Maximum (PETM): Geochemistry, Geophysics, Geosystems, v. 8, Q12002, doi: 10.1029/2007GC001784

Sluijs, A., Bowen, G.J., Brinkhuis, H., Lourens, L.J., and Thomas, E., 2007, The Palaeocene-Eocene thermal maximum super greenhouse: Biotic and geochemical signatures, age models and mechanisms of global change, in Williams, M., et al., eds., Deep time perspectives on climate change: Marrying the signal from computer models and biological proxies: Micropalaeontological Society Special Publication 2: Geological Society [London], p. 323-349.

Steenbrink, J., Kloosterboer-van Hoeve, M.L., and Hilgen, F.J., 2003, Millennialscale climate variations recorded in early Pliocene colour reflectance time series from the lacustrine Ptolemais Basin (NW Greece): Global and Planetary Change, v. 36, p. 47-75, doi: 10.1016/S0921-8181(02)00163-7.

Van Houten, F.B., 1944, Stratigraphy of the Willwood and Tatman Formations in northwestern Wyoming: Geological Society of America Bulletin, v. 55, p. 165-210.

Westerhold, T., Röhl, U., Laskar, J., Raffi, I., Bowles, J., Lourens, L.J., and Zachos, J.C., 2007, On the duration of magnetochrons C24r and C25n, and the timing of early Eocene global warming events: Implications from the ODP Leg 208 Walvis Ridge depth transect: Paleoceanography, v. 22, PA2201, doi: 10.1029/2006PA001322

Manuscript received 27 December 2007

Revised manuscript received 5 March 2008

Manuscript accepted 7 March 2008

Printed in USA 